Mirosław MATYJA

DOI : $10.14746 / \mathrm{pp} .2016 .21 .4 .2$

Londyn/Guadalajara

\title{
Is direct democracy in Switzerland dysfunctional?
}

\begin{abstract}
An important element shaping the political system of Switzerland was adopting the Federal Constitution in 1848. The current Federal Constitution of the Swiss Confederation was adopted in 1999. The current political system of this country can be referred to as directorial; however, because this specific system manifests itself mainly through the significant role of the cantons, it is also referred to as a 'parliamentary-cantonal' system. An important element of the system is the large degree of independence and self-reliance of the cantons and the communes. What determines the shape of the political parties and the socio-political division of Switzerland is the multiculturalism of the country. The fundamental democratic instruments in the country comprise: referenda; popular initiatives and popular assemblies. Dysfunctional qualities hinder the system, and even constitute a barrier for the effectiveness of the process of decision-making.
\end{abstract}

Key words: Swiss political system, direct democracy, federalism, democratic instruments, dysfunctionality

\section{Introduction}

D emocracy', which literally means 'the rule of the people', is a term that initially was synonymous with a political system in which the citizens exercised power by voting directly on all matters concerning their state.

Modern democracies, in the political sense (with the criterion of a governance system), can be divided into: parliamentary-cabinet democracies (parliamentarism); presidential democracies (presidentialism); and parliamentary-presidential democracies. However, there are countries with political systems so different from the rest that they do not belong to any of the above-mentioned types. For example, the political system of Switzerland is a directorial democracy (representative democracy) or a direct democracy, and represents a unique political solution in the world of traditional democracies (Meyer, 2009).

In the doctrines of many countries, the notion of a direct democracy is viewed as a characteristic of the governance system of ancient Athens, and of other Greek democracies. Nowadays, there can only be semi-direct democracies, because two of the necessary conditions that would allow contemporary institutions to be considered as an institution of direct democracy, i.e. the unity of place and time and the participation of the entire collective subject of the sovereignty in all stages of the decisionmaking (from submitting a motion to approving the decision), cannot be simultaneously fulfilled. However, considering the finality of the vote of a sovereign in the decision-making process, it can be assumed that a vast majority of the institutions that allow a sovereign to participate in exercising power have the nature of a direct democracy; whereas a system that is limited to public consultations and indirect initiatives is 
a semi-direct democracy, as it is only in such cases that a sovereign does not make the final decisions (Kost, 2008).

Currently, we can distinguish the following institutions as representing this form of direct democracy: popular assemblies, popular initiatives, referenda, plebiscites, abrogative referenda, recalls and public consultations.

A direct democracy is a political system in which the decisions are made through a popular vote (a referendum), where all of the people with voting rights are eligible to take part. Thus, the citizens have a greater and more direct influence on the decisions made than in the majority of countries (with indirect democracies). The Swiss direct democracy is based, first and foremost, on two instruments: popular initiatives and referenda.

Research question of this text reads: Is the system of swiss direct democracy dysfunctional?

\section{Historical and socio-political issues}

The history of the development of Switzerland's statehood is undoubtedly the key to understanding the functioning of Swiss political institutions and the country's political system.

An important element shaping the political system of Switzerland was adopting the Federal Constitution in 1848, when a governance system rooted in direct democracy was established. Consequently, the management of local matters was left to cantonal authorities. The state was defined as religiously neutral, and at the same time, a rule of territoriality was adopted, according to which all languages used in the multilingual federation were recognised as official and individual linguistic communities acquired the right to have representation in the state institutions which was proportional to their size.

The current Federal Constitution of the Swiss Confederation was adopted in 1999. ${ }^{1}$ Its reforms mainly concerned the system of basic civil liberties and the relationship between the federation and the cantons.

Throughout the course of history, the Swiss political system has evolved and its democratic nature has begun to mature and improve. The current political system of this country can be referred to as directorial; however, because this specific system manifests itself mainly through the significant role of the cantons, it is also referred to as a 'parliamentary-cantonal' system. An important element of the system, as mentioned above, is the large degree of independence and self-reliance of the cantons and the communes (Frey, 2005). Each canton has its own constitution, government and parliament, although the laws of the cantons have to be in accordance with the national laws. Furthermore, the cantons forming the Swiss Confederation have been granted many rights that are typical of sovereign states (Matyja, 2009a).

What determines the shape of the political parties and the socio-political division of Switzerland is, first and foremost, the multiculturalism of the country (Bickel, Schläpfer,

${ }^{1}$ Germ. Bundesverfassung der Schweizerischen Eidgenossenschaft, fr. Constitution fédérale de la Confédération suisse, it. Costituzione federale della Confederazione Svizzera, ret. Constituziun federala da la Confederaziun svizra. 
2000). This multiculturalism is based on two pillars: firstly, the Swiss multiculturalism discards the idea of creating a monocultural and monolingual nation state; and secondly, it is based on democratic power which favours and strengthens the division of political power. Thus, the political power is divided among religious groups (Protestants and Catholics), linguistic groups (German, French, Italian and Rhaeto-Romanic) and professional groups (employers and trade unions).

The Swiss Confederation is one of the first federations in the world that was created through many formerly sovereign countries becoming closer to one another. Swiss federalism is, therefore, an example of federalism through integration, and the name 'Confederation' has only a symbolic meaning. A confederation, in the literal sense of the word and according to international laws, is not a state, but is instead a loose complex that usually precedes the institution of a federal state. The bicameralism of a parliament, which differs significantly from the bicameralism in a unitary state, plays an important role in federalism. Also, the Federal Assembly, just like all parliaments of federal states, is composed of two houses: the National Council and the Council of States. The former is composed of the representatives of the nation, so that during the elections for the National Council and the distribution of seats, the population of each canton is taken into consideration; whereas the latter is composed of the representatives of the cantons, and each canton receives two seats, regardless of the number of its residents (Blöchliger, 2005).

An important governance tool in the current constitution is Article 3, which primarily defines the federal system:

"The Cantons are sovereign insofar as their sovereignty is not limited by the Federal Constitution; they shall exercise all rights which are not transferred to the Confederation."

This Article is basically the foundation of the Swiss political system, and indicates a clear role of the principle of subsidiarity.

The Constitution allows all state bodies to operate within the limits of the law and in good faith, and their competencies are divided between the federal and cantonal authorities (Linder, 2005, pp. 75-100). The former carry out only those tasks that are clearly transferred to them by the Constitution, and any disputes over the competencies are settled through negotiations and mediations. Thus, the two ranks of power overlap, but each canton has its own bodies, constitutions and laws. Also, the duty to exercise the laws of the federation are fairly often transferred to the cantons, but this is not a general rule. It is a decentralised federalism based on the principle of subsidiarity. This means that all decisions are made at a grass-roots level, where the citizens are directly involved in the process. The decisions that cannot be made at a communal level are made by the cantonal authorities, and it is a general rule that the federal government will enact laws for many domains, but will leaves their implementation to the cantons, which will exercise them as is appropriate to their own standards (Matyja, 2009d).

The Swiss political system is unique in many respects: from its regulations (uncharacteristic of European countries) concerning the functioning of its executives, through to its very strong federal system, and its regulations concerning the political parties (Matyja, 2009a). 
Usually, under a permanent coalition, small parties do not play an important role in the states' political processes. The opposition for the authorities is instead the society, which voices its opinions through the institutions of direct democracy, i.e. referenda (Matyja, 2009b, pp. 46-47).

Another characteristic of the system in Switzerland is that political competitiveness is maintained only during the election stage, and is then suspended in the governance stage. Therefore, it represents a fairly astonishing case of a consensual democracy (Vatter, 2014). The government, that is the seven-person Federal Council, is not established through political bargaining. Instead, the government is formed based on four principles: the political principle; the cantonal principle, which always ensures seats in the government for the three largest cantons (Zürich, Basel, and Vaud); the linguistic principle, which dictates that at least two ministers will represent the minority languages; and the religious principle, which enforces a religious balance among the ministers (Gabriel, 1997). These principles are referred to as the 'magic formula', which was strictly followed from 1959 to 2003. As a result, regardless of the election results, for 44 years the power was exercised generally by the four main parties that represented almost $70 \%$ of the society.

\section{Instruments of swiss direct democracy}

The idea of citizens taking part in political decisions through a direct democracy constitutes a significant part of Switzerland's history. The fundamental democratic instruments in the country comprise:

- referenda;

- popular initiatives; and

- popular assemblies (Matyja, 2009b).

The referendum is a basic and a centuries-old institution of direct democracies, which enables the country's citizens to make a decision on a public matter. It is used the most widely at the communal level, and, to a lesser degree, at the cantonal level and the federal level. A referendum constitutes a social response that is binding for the authorities, and that gives rise to legal consequences in its relevant domain.

There are two forms of this instrument that function in Switzerland at the federal level: obligatory referenda and facultative referenda. Article 140 of the Swiss Constitution stipulates that an obligatory referendum, first introduced in 1848, will apply to three groups of issues:

- changes to the Federal Constitution;

- accessions to organisations of collective security and supranational communities;

- urgent federal acts without a constitutional basis and that have a period of validity of longer than a year.

Facultative referenda, also referred to as abrogative referenda, were introduced in 1874. These are held to express an objection to solutions that have been adopted by the governance system in force, i.e. they are used against an enacted legislation. The following issues can be put to a vote: federal acts, federal acts with a period of validity of longer than a year, and international agreements. 
The second instrument is a popular initiative, and is mentioned in Articles 138, 139 and $139 \mathrm{~b}$ of the Constitution of 1999. It plays an important role in the Swiss model of direct democracy, and may concern a partial or total revision of the Federal Constitution. In fact, a complete change of the Constitution may be requested by 100,000 citizens who are entitled to vote, who must collect the required signatures within a period of 18 months (Linder, 2005).

A popular assembly is a gathering of certain entitled citizens, who congregate outdoors, in a central square of a given canton (the Landsgemeindeplatz) to discuss and make decisions about the most important cantonal matters. Each popular assembly concerns matters that are important for the residents, and during these annual meetings, decisions are made on legal issues, cantonal expenditures, etc. Each participant can speak during a debate (Hug, 2004, pp. 321-336). For practical purposes, the Landsgemeinde has been abolished in all but two cantons: Glarus and Appenzell Innerhoden (where it has remained the highest political institution at the cantonal level).

\section{Functionality and dysfunctionality of direct democracy in Switzerland}

The functionality of this system of direct democracy is related, first and foremost, to the broadly defined participation of the citizens and political players in the decisionmaking processes of the state, the cantons and the communes.

Firstly, direct democracy makes it easier for citizens to take part in the direct decisionmaking on political matters. Even political entities that are not a part of the government structure are involved in making decisions about political processes. As such, citizens become aware that they are responsible for the decisions that are made at a ballot box.

Secondly, each political entity can successfully articulate its own demands. Even initiatives and referenda are carried out that have no chance of success from the beginning; however, these do have a political input and can have an indirect influence on shaping public opinions.

Thirdly, the direct democracy is characterised by a strong tendency to reach compromises and to take public opinion into account. For politicians, this system entails being in constant contact with their society for fear of unforeseen popular initiative taking place. In particular, this offers a chance for minorities to force their suggestions and political demands to fruition.

Fourthly, in the system of direct democracy, the political decisions are widely accepted by all the players in the political, economic and social scenes. The political decisions made in a referendum are undoubtedly more popular among the public than the decisions which are forced upon them by politicians.

Fifthly, a direct democracy fulfils two important system functions in the decisionmaking process: the function of political communication; and the function of political socialisation. The first function is related to the many political entities that are involved in a decision-making process. This leads to a situation wherein what is referred to as the political knowledge in a society reaches a higher level than in the political systems that are based on a representative democracy. It is also related to striving for compromises and involves a full range of political and social connections through which information is 
exchanged. In turn, the political socialisation involved in taking part in the direct democracy reinforces some basic democratic laws (such as respect for the arguments of one's political opponents) in the social consciousness.

Nonetheless, a direct democracy, just as all known democratic systems, also has some dysfunctional qualities. However, of the solution does not involve eliminating these qualities completely; rather, it is more about a question of minimising their negative consequences, which can generate undesirable directions of economic and socio-political developments.

The dysfunctionality of this form of democracy, just like its functionality, is a complex and multidimensional issue (Matyja, 2015, p. 59).

Firstly, this system enables citizens to participate freely in the political life of their state; however, in practise, only a small minority of the society actively participates in this process. It is a minority that (leaving the political system aside) takes over, or would take over the public initiative, and would participate actively in every decision-making process of the state. The political elites, referred to as the classe politique, whose opinion and beliefs are valued by the majority of the society, constitute this minority.

Secondly, the direct democracy slows down the decision-making, and thus hinders the process of arriving at a desirable solution. Due to the fact that the political process has many different participants (the political parties, interest groups and the society), the search for a compromise can be long. Therefore, it is a costly and time-consuming process.

Thirdly, the direct democracy weakens the position of established political players, as it creates an opportunity to omit the decisive competencies of state bodies. Simultaneously, it strengthens the role of the opposition and allows for more negotiations in decisions by discussing the opposing arguments, searching for compromises, and increasing consultancies; whereas personal political confrontations between contracting parties occur considerably less frequently than in a representative-parliamentary democracy. In this way, interest groups may emphasise topics that are important for their particular interests without suffering any political consequences. Also, due to this policy, the interest groups come between society and the state as competition for the political parties, which in turn, weakens the role of the political parties.

Next, direct democracy, with the multitude and diversity of the decisions made by the electors, can cause the society to become politically passive. Electors are not able to keep informing one another about all the changes because the information cost would be too high, especially in the case of decisions on complex matters.

Lastly, the system of direct democracy may exacerbate political conflicts, which may happen particularly in voting where the stakes are all or nothing. There is the risk that a political struggle will escalate, and sometimes, the majority may even create a tyranny over the minority. By reducing the decisive options to either 'yes' or 'no', the popular vote polarises stances and limits the options for negotiations, supplements and compromises.

There are some examples of dysfunctionality of the direct democracy with regard to the socio-political, economic and cultural issues of Switzerland. The federal referendum concerning the accession of Switzerland to the European Economic Area in 1992; the cantonal referenda concerning the integration of the Muslim minority in Switzerland; and the federal referendum 'Against the Construction of Minarets' ('Stop the Minarets'). ${ }^{2}$

${ }^{2}$ See A. Schaer (2009), Minarettinitiative - Im Widerspruch zur Verfassung, ,,akzente”, no. 2, p. 5; M. Stüssi (2008), Muss das Parlament die Minarettverbotsinitiative für ungültig erklären?, Luzern; 


\section{Conclusions}

The presented analyse confirm the idea that some decisions involving the use of the instruments of a direct democracy can have a dysfunctional nature and a negative influence on the socio-political, economic and cultural policies in the examined country.

The importance of the model of participatory democracy in the socio-political life of Switzerland should also be emphasised. Direct democracy educates the country's citizens, shapes their sense of responsibility and their ability to co-operate, and most importantly, it deepens civil competencies and causes citizens to vote and to act rationally. This argument seems even more important in the face of the great threat posed to democracy by the dissolution of social bonds and the passiveness of citizens. The forms of bottom-up control over the state should be all the more guaranteed, as it is simultaneously a means of controlling the central authorities.

Direct democracy should satisfy not only the interests of the political system, but also the important psychological needs of the citizens, such as feeling settled, belonging to a group and group integration, the sense of a common bond and a sense of solidarity.

We should also agree with the statement that frequent referenda increase the social control of the political process and the quality of the laws formulated in this manner. In turn, the decrease in the number of Swiss citizens who participate in the popular votes results from them having become tired of the frequency of the referenda. Nevertheless, the constitutional position of this instrument in Switzerland is beyond question. The very possibility of a referendum being held means taking into account the interests of the entire federation.

Therefore, the instruments of direct democracy, especially referenda, stabilise the state and guarantee that legal order is maintained and the acceptance of a state of justice.

In conclusion, it should be stated that the functionality and the dysfunctionality of the Swiss political system concerns only the legally and constitutionally guaranteed legal order. While its dysfunctional qualities hinder the system, and even constitute a barrier for the effectiveness of the process of decision-making, they do not threaten the overall functionality of the system of direct democracy.

\section{Bibliography}

Die viersprachige Schweiz (2000), ed. H. Bickel, R. Schläpfer, Sauerländer Verl., Aarau-Frankfurt am Main-Salzburg.

Blöchliger H. (2005), Kantone - Baustelle Föderalismus. Metropolitanregionen versus Kantone. Untersuchungen und Vorschläge für eine Revitalisierung der Schweiz, Zürich.

Föderalismus - Zukunftstauglich?! (2005), ed. R. L. Frey, Zürich.

A. Vatter (2011), Vom Schächt- zum Minarettverbot, Zürich; A. Vatter, D. Danaci (2010), Mehrheitstyrannei durch Volksentscheide? Zum Spannungsverhältnis zwischen direkter Demokratie und Minderheitenschutz, „Politische Vierteljahresschrift“, no. 51 (2), pp. 205-222; W. Lienmann (2007), Kippa, Kruzifix, Kopftuch - Kulturkampf? Der Rechtsstaat als Herausforderung und Chance heutiger Religionen, in: Religionsfreiheit. Schweizerische Perspektiven, ed. T. H. Kuhn, TVZ, Zürich, pp. 151-177; M. Matyja (2014), Granice demokracji. Wptyw szwajcarskiego systemu demokracji bezpośredniej na proces integracyjny muzutmańskiej mniejszości religijnej, Poligraf, Brzezia Łąka. 
Gabriel J. M. (1997), Das politische System der Schweiz, Bern.

Hug S. (2004), Occurrence and Policy Consequences of Referendums, „Journal of Theoretical Politics", vol. 16, pp. 321-336.

Kost A. (2008), Direkte Demokratie, Wiesbaden.

Lienmann W. (2007), Kippa, Kruzifix, Kopftuch - Kulturkampf? Der Rechtsstaat als Herausforderung und Chance heutiger Religionen, in: Religionsfreiheit. Schweizerische Perspektiven, ed. T. H. Kuhn, TVZ, Zürich, pp. 151-177.

Linder W. (2005), Schweizerische Demokratie. Institutionen - Prozesse - Perspektiven, Bern-Stuttgart-Wien.

Matyja M. (2009a), Besonderheiten des politischen Systems der Schweiz. Föderalismus und direkte Demokratie, „Europa Regionum”, no. 12.

Matyja M. (2009b), Oddolna samorząność i partycypacja obywateli - specyfika systemu federalnego Szwajcarii, „Obywatel”, no. 2.

Matyja M. (2009c), System polityczny Szwajcarii. Federalizm i demokracja bezpośrednia, „Kultura i Historia", vol. 16.

Matyja M. (2009d), Szwajcarski system federalny, „Stosunki Międzynarodowe”, 30.11.2009, http:// www.stosunki.pl/?q=content/szwajcarski-system-federalny.

Matyja M. (2014), Granice demokracji. Wpływ szwajcarskiego systemu demokracji bezpośredniej na proces integracyjny muzutmańskiej mniejszości religijnej, Poligraf, Brzezia Łąka.

Matyja M. (2015), Dysfunkcjonalność szwajcarskiego systemu demokracji bezpośredniej na przykładzie procesu integracji mniejszości muzułmańskiej, "Studia Politicae Universitatis Silesiensis", no. 14.

Meyer T. (2009), Was ist Demokratie? Eine diskursive Einführung, Wiesbaden.

Neidhart L. (2002), Die politische Schweiz. Fundamente und Institutionen, Zürich.

Schaer A. (2009), Probleme lösen, nicht schaffen, „EVP Info”, no. 4.

Vatter A. (2014), Das politische System der Schweiz, Nomos, Baden-Baden.

Vatter A., Danaci D. (2010), Mehrheitstyrannei durch Volksentscheide? Zum Spannungsverhältnis zwischen direkter Demokratie und Minderheitenschutz, "Politische Vierteljahresschrift", no. 51 (2), pp. 205-222.

\section{Czy demokracja bezpośrednia w Szwajcarii jest dysfunkcjonalna?}

\section{Streszczenie}

Uchwalenie Konstytucji Federalnej w 1848 roku było istotne dla kształtowania systemu politycznego Szwajcarii. Aktualna Konstytucja Federalna Konfederacji Szwajcarskiej została uchwalona w 1999 roku. Obecnie system tego kraju można określić mianem parlamentarno-komitetowego (system konwentu). Ze względu jednak na jego specyfikę, objawiającą się w głównie w dużej roli kantonów, określany jest także jako parlamentarno-kantonalny. Istotnym elementem systemu jest duża niezależność i samodzielność kantonów, a także gmin. Elementem determinującym kształt partii politycznych i podział socjopolityczny Szwajcarii jest przede wszystkim jej wielokulturowość. Zasadniczymi instrumentami demokratycznymi w tym państwie są: referendum, inicjatywa ludowa, zgromadzenie ludowe. Dysfunkcjonalne elementy szwajcarskiej demokracji bezpośredniej blokują efektywność procesu decyzyjnego w tym systemie politycznym.

Słowa kluczowe: Szwajcarski system polityczny, demokracja bezpośrednia, federalizm, instrumenty demokratyczne, dysfunkcjonalność 